\title{
Antibody-mediated Killing of Suppressor T Lymphocytes as a Possible Cause of Macroglobulinemia in the Tropical Splenomegaly Syndrome
}

\author{
Willy F. Piessens, Stephen L. Hoffman, Ahmed A. Wadee, Patricia W. Piessens, Sutanti Ratiwayanto, Liliana Kurniawan, \\ James R. Campbell, Haryani A. Marwoto, and Larry L. Laughlin \\ Division of Hematology, Department of Medicine, Brigham and Women's Hospital and Harvard Medical School, and Department of \\ Tropical Public Health, Harvard School of Public Health, Boston, Massachusetts 02115; United States Navy Medical Research \\ Unit No. 2, Jakarta Detachment, Jakarta, Indonesia; National Institute of Health, Research and Development \\ of the Ministry of Health, Jakarta, Indonesia
}

\begin{abstract}
To investigate the pathogenesis of macroglobulinemia in the tropical splenomegaly syndrome (TSS), we assessed the functional activity of $B$ lymphocytes and $T$ cell subsets in a pokeweed mitogen-driven assay of immunoglobulin synthesis. Mononuclear cells from patients with TSS produced more IgM than cells from village or from distant controls. This appeared to result from a decrease in the number and/or activity of suppressor $\mathrm{T}$ cells of the $\mathrm{T8}^{+}$phenotype. The lack of functional suppressor $T$ lymphocytes was associated with the presence in sera from patients with TSS of IgM antibodies that specifically killed $\mathrm{T8}^{+}, 9.3^{-}, 60.1^{+} \mathrm{T}$ cells from normal donors. These results support the hypothesis that macroglobulinemia in TSS results from defective immunoregulatory control of $B$ cell function, and that this may be caused by lysis of suppressor $T$ cells by specific lymphocytotoxic antibodies produced by patients with this syndrome.
\end{abstract}

\section{Introduction}

Tropical splenomegaly syndrome (TSS) ${ }^{1}$ is a term used to describe a morbid condition in adult long-term residents of malarious areas characterized by massive splenomegaly and markedly elevated levels of serum IgM that generally improves with prolonged malaria chemosuppression $(1,2)$. It has been proposed that splenomegaly in this syndrome results from chronic stimulation of splenic reticuloendothelial cells engaged in the clearing of high molecular weight immune complexes and IgM aggregates produced in excessive amounts because of unbridled immune responses to malarial antigens or mitogens (2-4).

Because not all adults living in malarious areas develop TSS, this hypothesis implies a defect in the regulation of immune responses in patients with this syndrome. We previously observed imbalances in the relative proportions of im-

Dr. Wadee is the recipient of a fellowship from the South African Research Council. Address reprint requests to Dr. Piessens at the Harvard School of Public Health.

Received for publication 21 September 1984 and in revised form 6 February 1985.

1. Abbreviations used in this paper: MNC, mononuclear cells; PWM, pokeweed mitogen; TCM, tissue culture medium; TSS, tropical splenomegaly syndrome.

J. Clin. Invest.

(c) The American Society for Clinical Investigation, Inc.

0021-9738/85/06/1821/07 \$1.00

Volume 75 , June 1985, 1821-1827 munoregulatory thymus-dependent $(T)$ lymphocytes in peripheral blood of patients with TSS, a finding that is consistent with this hypothesis (5). However, these studies failed to document that such phenotypic changes resulted in functional abnormalities that could account for the marked hyperproduction of IgM in patients with TSS. These studies also did not address the pathogenesis of the apparent imbalance in the immunoregulatory $\mathrm{T}$ cells in this syndrome.

We now have examined the functional activity of various lymphocyte populations from patients with TSS and report here that these individuals lack functional suppressor $\mathrm{T}$ lymphocytes. Our studies suggest that this may be caused by the effect of lymphocytotoxic antibodies elicited during this syndrome. These findings provide a possible explanation for the marked polyclonal macroglobulinemia that is characteristic of TSS.

\section{Methods}

Blood donors. In a previous study, we enumerated circulating $\mathrm{T}$ and B lymphocytes in a large number of inhabitants of Robek, Flores, Indonesia, where TSS is common and in a group of residents of Jakarta, Java, Indonesia, where malaria is not transmitted (5). This information was used to select blood donors for the present study. All participants were adult volunteers assessed clinically and parasitologically as previously described (5). None of the donors had detectable filarial or malarial parasites in their blood, or suffered from an acute febrile illness at the time of study.

In this report, "patients" refers to individuals with TSS, "village controls" to residents of Robek without splenomegaly or with spleens palpable only on deep inspiration, and "distant controls" to residents of Jakarta or to normal volunteers living in the United States.

Preparation of sera. To prepare serum samples, blood was allowed to clot for 10-12 h at ambient temperature before centrifugation. Sera were frozen in liquid nitrogen and maintained at $-70^{\circ} \mathrm{C}$ until used.

Isolation of lymphocyte populations. Mononuclear cells (MNC) were prepared by centrifugation of heparinized venous blood on ficollHypaque gradients (Pharmacia Fine Chemicals, Piscataway, NJ). Blood collected in Flores was maintained at ambient temperature (ca. $24^{\circ} \mathrm{C}$ ) in polypropylene tubes during the 6-10-h period required for its transport to the laboratory. Blood obtained from control donors in Jakarta likewise was kept at room temperature for the same period before being used.

To prepare $\mathrm{T}$ cell populations enriched in $\mathrm{T}^{+}$or $\mathrm{T}^{+}$cells, MNC were first incubated in $25-\mathrm{cm}^{2}$ tissue culture flasks previously coated with the IgG fraction of goat anti-human immunoglobulin serum (Cappel Laboratories, Cochranville, PA; $15 \mu \mathrm{g} / \mathrm{ml}$ PBS, $5 \mathrm{ml} /$ flask) for $30 \mathrm{~min}$ at $37^{\circ} \mathrm{C}$. Nonadherent cells recovered from these flasks were then incubated with either OKT8 or OKT4 monoclonal antibody (Ortho Diagnostic Systems Inc., Raritan, NJ) and rabbit complement, as previously described (6). Residual viable cells were isolated by centrifugation on Ficoll-Hypaque gradients maintained at $4^{\circ} \mathrm{C}$, washed 
twice with tissue culture medium (RPMI 1640, made to contain 10\% heat-inactivated fetal calf serum, $2 \mathrm{mM}$ L-glutamine, and antibiotics), and counted. Over $90 \%$ of cells recovered at the end of this procedure were $\mathrm{T}$ cells with the $\mathrm{T} 3^{+} \mathrm{T}^{+}$or $\mathrm{T} 3^{+} \mathrm{T} 4^{+}$phenotype, as determined by indirect immunofluorescence.

A similar two-step procedure was used to prepare B cell-enriched fractions from MNC. In this case, MNC were first incubated in culture flasks coated with bovine serum albumin, and then treated with OKT3 plus complement. $78-92 \%$ of all viable cells recovered as described above consisted of B cells, identified by direct immunofluorescence with rabbit anti-human $\gamma$-globulin serum (Cappel Laboratories). This cell population also contained $3-7 \%$ monocytes, $\sim 5 \% \mathrm{~T}^{+} \mathrm{T}$ cells, 5$8 \%$ eosinophilic and basophilic polymorphonuclear cells, and 10-15\% large granular lymphocytes.

In vitro production of immunoglobulin. Cultures were performed in 5-ml test tubes containing either $1 \times 10^{6} \mathrm{MNC}$ or $2.5 \times 10^{5} \mathrm{~B}$ cellenriched fractions plus varying numbers of purified $\mathrm{T}^{+}$or $\mathrm{T}^{+}$ lymphocytes in $1 \mathrm{ml}$ of culture medium containing $10 \%$ heat-inactivated fetal calf serum. Pokeweed mitogen (PWM, Gibco Laboratories, Grand Island, NY) was added to a final dilution of 1:200.

Supernatants harvested after $7 \mathrm{~d}$ of culture were analyzed for IgM and IgG content with a solid-phase radioimmunoassay similar to that described by McLachlan et al. (7). Immunoglobulin levels in supernatants of replicate cells cultured for $1 \mathrm{~h}$ in the presence of PWM were subtracted from values obtained when cells were cultured for $7 \mathrm{~d}$ with or without antigen, in order to minimize the contribution of minute amounts of cell donor serum on the measurements.

Assay of inducible suppressor T lymphocytes. In these experiments, MNC from control donors or patients with TSS were cultured for $3 \mathrm{~d}$ in tissue culture medium (TCM) containing $10 \mu \mathrm{g} / \mathrm{ml}$ concanavalin A (Miles Laboratories, Inc., Elkhart, IN). This mitogen was added to control cultures immediately prior to recovery of the cells. These were washed three times in medium containing $100 \mu \mathrm{g} / \mathrm{ml} \alpha$-methylmannoside and counted. Equal numbers of these activated and nonactivated suppressor cells were then co-cultured with $1 \times 10^{6}$ indicator MNC (from control donors or patients, see results), and the amount of immunoglobulin produced was determined as described.

Detection of lymphocytotoxic activity in sera. A previously described ${ }^{51} \mathrm{Cr}$ release assay was adapted to quantitate lymphocytotoxic activity of sera and fractions derived therefrom (8). In brief, cells from normal donors (see below) were labeled with $\mathrm{Na}^{51} \mathrm{CrO}_{4}$ (New England Nuclear, Boston, MA) and washed extensively. The assay was performed by adding into microfuge tubes (PD-2 tubes, Luckham Ltd., Burgess Hill, United Kingdom) $50 \mu \mathrm{l}$ of serum and $50 \mu \mathrm{l}$ of cells $\left(5 \times 10^{6} / \mathrm{ml}\right)$. After $30 \mathrm{~min}$ of incubation at room temperature, $50 \mu \mathrm{l}$ of fresh rabbit complement (Cedarlane, Ontario, Canada) was added. The tubes were then incubated at $37^{\circ} \mathrm{C}$ for $6 \mathrm{~h}$. $(250 \mu \mathrm{l}$ of TCM was added to the cell suspensions after $2 \mathrm{~h}$ of culture.) At the end of the incubation period, $100 \mu l$ of supernatant was removed from the test tube, and placed into a second tube. Radioactivity in the paired tubes was measured in a Packard gamma counter (Packard Instrument Co., Inc., Downers Grove, IL). Percent ${ }^{51} \mathrm{Cr}$ release was calculated by the formula $\%{ }^{51} \mathrm{Cr}$ release $=100 \times[\mathrm{cpm}$ (tube 2) $\times 4] /[\mathrm{cpm}$ (tube 1) $+\mathrm{cpm}$ (tube 2)].

This formula expresses the amount of radioactivity released in culture supernatant (the numerator) as a percentage of the total (released and cell-associated) amount of radioactivity present in each assay tube (the denominator). This minimizes the effect of minor variations that inevitably occur when a stock suspension of radiolabeled targets is dispersed into a large number of assay tubes (8). All experiments were done in triplicate, thus allowing statistical analysis of the results by $t$ test.

Target cells in this assay were prepared from either unstimulated or concanavalin A-activated MNC from normal volunteers. Nonadherent MNC recovered from culture dishes were treated with OKT3, OKT4, or OKT8 antibody plus complement to yield populations enriched in $\mathrm{B}$ lymphocytes, $\mathrm{T}^{+}$cells, and $\mathrm{T}^{+}$lymphocytes, respectively. In some experiments, $\mathrm{T}^{+}$lymphocytes were further fractionated into $\mathrm{T}^{+} 9.3^{+}, \mathrm{T}^{+} 9.3^{-}, \mathrm{T}^{+} 60.1^{+}$, and $\mathrm{T}^{+} 60.1^{-}$subpopulations as described by Lum et al. (9). The monoclonal antibodies designated 9.3 and 60.1 were a generous gift of Dr. J. A. Hanson, University of Washington, Seattle. These antibodies identify antigens on $\mathrm{T}^{+}$killer cells and $\mathrm{T}^{+}$suppressor cells, respectively, (reference 9 and personal communication).

Fractionation of sera. Pooled sera from 10 patients with TSS previously shown to contain lymphocytotoxic activity were fractionated by $\mathrm{NH}_{4} \mathrm{SO}_{4}$ precipitation (10). To determine the Ig class of anti- $\mathrm{T}$ cell antibodies, IgG and IgM were isolated from the Ig-rich fraction by affinity chromatography on columns containing monospecific antihuman IgG or IgM covalently linked to Sepharose 4B (Miles Laboratories, Inc.).

\section{Results}

Immunoglobulin production by MNC from patients with TSS. The catabolic rate of radiolabeled IgM in patients with TSS is similar to that in individuals without splenomegaly (11). Because this finding suggested that macroglobulinemia in this syndrome is due to increased immunoglobulin synthesis, we studied in vitro production of IgM by MNC from patients with TSS. These cells produced significantly more IgM during $7 \mathrm{~d}$ of culture than MNC from village control donors. Not unexpectedly, higher amounts of immunoglobulin were produced by cells from donors with elevated serum IgM levels (Fig. 1).

Because our previous studies indicated that patients with TSS lack circulating $\mathrm{T}^{+}$lymphocytes (5), we next examined whether differences in the cellular composition of MNC from various donors could account for these findings. For this purpose, we measured IgM produced in cultures containing fixed numbers of $\mathrm{B}$ cells, $\mathrm{T}^{+}$cells, and $\mathrm{T} 8^{+}$lymphocytes isolated from the blood of single donors. Under these culture conditions, cells from patients with TSS also produced significantly more IgM than those from village control donors regardless of whether or not PWM was added (Table I). Thus, standardization of the cellular composition in the in vitro assay did not reduce IgM production by peripheral blood cells from patients with TSS.

Measurement of $\operatorname{lgG}$ produced in the same cultures yielded different results. Unstimulated cells from village control donors and from patients with TSS produced similar amounts of IgG, which averaged two to three times that produced by cells from

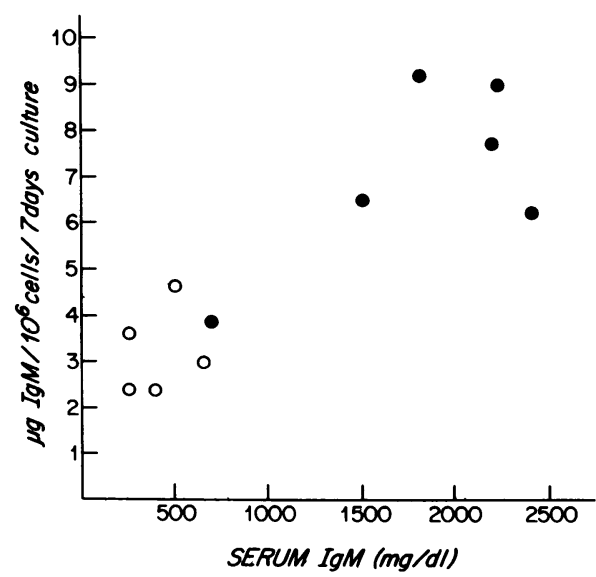

Figure 1. In vitro production of IgM by MNC from patients with TSS. Data shown are means of triplicate cultures of $1 \times 10^{6} \mathrm{MNC}$ stimulated with PWM. (0) Village controls; (๑) patients with TSS. 
distant control donors. These in vitro findings are strikingly similar to what is observed in vivo (5). In contrast, PWMstimulated cells from all donors produced similar amounts of IgG in culture (Table I).

Functional activity of lymphocyte populations from patients with TSS. The results of these initial experiments suggested that overproduction of IgM by B cells from patients with TSS may result from defects in the regulation of immunoglobulin secretion by $T$ lymphocytes. To investigate this possibility, we examined the functional activity of $\mathrm{B}$ cells, $\mathrm{T} 4^{+}$lymphocytes, and $\mathrm{T8}^{+} \mathrm{T}$ cells from patients with TSS in co-culture experiments.

$\mathrm{T4}^{+}$lymphocytes from TSS donors augmented production of IgM by B cells from normal donors to the same extent as $\mathrm{T4}^{+}$cells from village control donors. Likewise, the addition of $\mathrm{T}^{+}$lymphocytes to B cells from patients with TSS increased the amount of IgM produced in these cultures, regardless of the donor origin of the $\mathrm{T4}^{+}$cells. The results of a typical experiment, one of three performed, are shown in Table II. These findings indicate that hyperproduction of IgM in patients with TSS is not caused by excessive helper activity of these individuals' $\mathrm{T4}^{+}$lymphocytes or by unusual sensitivity of their $B$ cells to $T$ cell help.

In marked contrast, $\mathrm{T}^{+}$lymphocytes from patients with TSS suppressed in vitro production of IgM by indicator B cells much less than $\mathrm{T}^{+}$cells from village control donors (Table III). On the other hand, B lymphocytes from TSS donors could be readily suppressed by $\mathrm{T}^{+}$cells from village or distant control donors (Table III). It should be noted that $\mathrm{T}^{+}$ lymphocytes from TSS patients failed to suppress IgM production by syngeneic as well as allogeneic B cells (Table III, cf. line 3 with 6).

Thus, these experiments indicated that B cells from patients with TSS are responsive to the effects of immunoregulatory T cells, and pointed to an abnormality in the number and/or activity of suppressor $\mathrm{T}$ lymphocytes as a possible cause of the

Table I. Immunoglobulin Production in Cultures with Fixed Ratios of $B$ and $T$ Lymphocytes

\begin{tabular}{|c|c|c|c|c|}
\hline \multirow[b]{2}{*}{ Cell donor } & \multicolumn{2}{|l|}{$\operatorname{lgM}$} & \multicolumn{2}{|l|}{ IgG } \\
\hline & Without PWM & With PWM & Without PWM & With PWM \\
\hline & \multicolumn{2}{|c|}{$\mu g$ of $\mathrm{Ig} / 7 \mathrm{~d}$ of culture* } & \multicolumn{2}{|c|}{$\mu g$ of $\mathrm{Ig} / 7 \mathrm{~d}$ of culture* } \\
\hline \multicolumn{5}{|c|}{ Distant control } \\
\hline 1 & 0.6 & 1.8 & 0.17 & 0.81 \\
\hline 2 & 0.3 & 1.4 & 0.15 & 0.07 \\
\hline 3 & 0.8 & 2.7 & 0.53 & 2.74 \\
\hline \multicolumn{5}{|c|}{ Village control } \\
\hline 1 & 1.1 & 3.2 & 0.92 & 2.06 \\
\hline 2 & 0.7 & 2.7 & 0.95 & 9.23 \\
\hline 3 & 0.5 & 3.6 & 0.34 & 4.62 \\
\hline \multicolumn{5}{|c|}{ TSS patient } \\
\hline 1 & 2.1 & 5.3 & 0.95 & 6.42 \\
\hline 2 & 1.6 & 6.1 & 0.98 & 1.24 \\
\hline 3 & 1.9 & 4.8 & 0.67 & 4.82 \\
\hline
\end{tabular}

Table II. Helper Activity of $\mathrm{T4}^{+}$

Lymphocytes from Patients with TSS

\begin{tabular}{lllll}
\hline Donor origin & & & \multicolumn{2}{l}{ Increase in IgM production* } \\
\cline { 1 - 2 } \cline { 5 - 5 } Indicator B cells & T4 $^{*}$ cells & & Without PWM & With PWM \\
\hline \multirow{3}{*}{ Distant control } & & & $\%$ & $\%$ \\
& Village control & & 286 & 289 \\
& TSS patient & & 291 & 354 \\
Village control & Village control & & 126 & 200 \\
& TSS patient & & 147 & 233 \\
TSS patient & Village control & & 132 & 175 \\
& TSS patient & & 173 & 202
\end{tabular}

* Increase in IgM produced during $7 \mathrm{~d}$ of culture by $2.5 \times 10^{5}$ indicator B cells co-cultured with $4 \times 10^{5} \mathrm{~T}^{+}$lymphocytes.

polyclonal hyperglobulinemia characteristic of this syndrome. To validate this concept, we compared the degree of suppression of IgM production by indicator cells (MNC from distant controls) co-cultured with concanavalin A-induced suppressor $\mathrm{T}$ cells from patients with TSS and village control donors. Concanavalin A-activated MNC from TSS donors suppressed IgM production significantly less than similar cells from village control donors (Table IV).

In contrast, IgG production in the same cultures was suppressed to the same extent by concanavalin A-activated MNC from TSS donors and villager controls (Table IV). Similar results were obtained when induced suppressor cells were co-cultured with syngeneic cells from the same TSS donor. In four experiments of this kind, IgM production was inhibited $8 \pm 14 \%$ (mean $\pm \mathrm{SD}$ ), whereas IgG production was decreased by $62-89 \%$.

Lymphotoxic activity of sera from patients with TSS. Taken together with our previous findings, the results just described indicated that patients with TSS lack circulating $\mathrm{T}^{+}$lymphocytes that function as suppressor cells of immunoglobulin

Table III. Suppressor Activity of $T 8^{+}$

Lymphocytes from Patients with TSS

\begin{tabular}{|c|c|c|c|c|}
\hline \multicolumn{2}{|l|}{ Donor origin } & \multicolumn{3}{|c|}{ Suppression of IgM production* } \\
\hline Indicator B cells & $\mathrm{T}^{+}$cells & Exp. 1 & Exp. 2 & Exp. 3 \\
\hline & & $\%$ & \% & $\%$ \\
\hline \multirow[t]{3}{*}{ Distant control } & Distant control & 69 & 58 & 86 \\
\hline & Village control & 74 & 84 & 92 \\
\hline & TSS patient & 6 & -10 & 21 \\
\hline \multirow[t]{3}{*}{ TSS Patient } & Distant control & 52 & 63 & 79 \\
\hline & Village control & 63 & 51 & 72 \\
\hline & TSS patient & 4 & 18 & 17 \\
\hline
\end{tabular}

* Decrease in IgM produced during $7 \mathrm{~d}$ of culture by $2.5 \times 10^{5}$ indicator B cells co-cultured with $4 \times 10^{5} \mathrm{~T}^{+}$lymphocytes and stimulated with PWM. Each experiment was performed with indicator B cells from different donors. Within each experiment B cells were cocultured with either syngeneic or allogeneic $\mathrm{T}^{+}$cells, as indicated. $\mathrm{T}^{+}$lymphocytes from TSS patients are significantly less able to suppress IgM production than similar cells from control donors $(P$ $<0.01$ by $t$ test). 
Table IV. Patients with TSS Lack Concanavalin A-inducible Suppressor Cells of IgM Production

\begin{tabular}{|c|c|c|c|c|}
\hline \multirow{3}{*}{$\begin{array}{l}\text { Donor origin of } \\
\text { Concanavalin } \\
\text { A-activated } \\
\text { suppressor cells }\end{array}$} & \multicolumn{4}{|c|}{ Suppression* } \\
\hline & \multicolumn{2}{|l|}{ IgM } & \multicolumn{2}{|l|}{$\operatorname{IgG}$} \\
\hline & Exp. 1 & Exp. 2 & Exp. 1 & Exp. 2 \\
\hline & $\%$ & $\%$ & $\%$ & $\%$ \\
\hline \multicolumn{5}{|l|}{ Village control } \\
\hline 1 & 91 & 60 & 80 & 74 \\
\hline 2 & 31 & 47 & 49 & 62 \\
\hline 3 & 77 & 68 & 75 & 85 \\
\hline \multicolumn{5}{|l|}{ TSS patient } \\
\hline 1 & -10 & 12 & 80 & 89 \\
\hline 2 & 3 & -4 & 62 & 75 \\
\hline 3 & 12 & 7 & 98 & 68 \\
\hline
\end{tabular}

* Cultures contained $5 \times 10^{5} \mathrm{MNC}$ from a distant control donor (Exp. 1) or a patient with TSS (Exp. 2) and $5 \times 10^{5}$ concanavalin Aactivated MNC.

synthesis. Because of the polyclonal nature of the hyperglobulinemia that characterizes this syndrome, we next examined the possibility that patients with TSS develop "autoantibodies" to suppressor T lymphocytes. This appeared to be the case.

Table V. Cytotoxic Effect of Sera on Lymphocytes from Normal Donors

\begin{tabular}{lll}
\hline Clinical status & $\mathrm{T} 8^{+}$cells $/ \mathrm{mm}^{3}$ blood & $\%{ }^{\text {s'Cr release* }}$ \\
\hline Distant control & \multicolumn{1}{l}{${ }^{*}$} & $\%$ \\
1 & 784 & 17 \\
2 & 1,002 & 14 \\
3 & 991 & 15 \\
4 & 802 & 16 \\
Village control & & \\
1 & 728 & 20 \\
2 & 901 & 19 \\
3 & 834 & 18 \\
4 & 752 & 18 \\
TSS Patient & & \\
1 & 437 & 27 \\
2 & 596 & 27 \\
3 & 316 & 24 \\
4 & 272 & 32 \\
5 & 359 & 28 \\
6 & 282 & 26 \\
7 & 414 & 25 \\
8 & 323 & 21 \\
& &
\end{tabular}

* Unfractionated MNC from normal donors were used as target cells. Spontaneous ${ }^{51} \mathrm{Cr}$ release from target cells was $14 \%$ in culture medium and $16 \%$ in medium containing fresh rabbit complement. After three cycles of freezing and thawing, target cells released $76 \%$ of incorporated radioactivity. Data shown are means of triplicate determinations. Similar results were obtained in two additional experiments. Sera from patients with TSS induce significantly more ${ }^{51} \mathrm{Cr}$ release than sera from the two control groups $(P<0.05$ by $t$ test).
Sera from patients with TSS and decreased levels of circulating $\mathrm{T8}^{+}$cells were cytotoxic for lymphocytes from normal donors, whereas sera from distant or village control donors with normal levels of $\mathrm{T}^{+}$cells were not (Table V). The lymphocytotoxic activity appeared to be a complementfixing IgM antibody, (Fig. 2). Studies to identify the nature of the target of the TSS lymphotoxin revealed that mitogenactivated $\mathrm{T}^{+}$cells were more susceptible to the lytic action of this antibody than nonactivated $\mathrm{T}^{+}$cells (Table VI) and that B lymphocytes were not killed by TSS sera (results not shown). Within the $\mathrm{T}^{+}$population, lymphocytes with the $60.1^{+}$or 9.3- phenotype were killed by this antibody, whereas the reciprocal $60.1^{-}$or $9.3^{+}$population was not (Fig. 3). Thus, sera from patients with TSS appeared to react with the subset of $\mathrm{T}^{+}$lymphocytes that bears phenotypic markers of suppressor $T$ cells.

To confirm this tentative conclusion, we compared immunoglobulin production by equal numbers of MNC from normal donors previously treated in vitro with complement plus pooled sera from TSS or village control donors. Pretreatment with TSS sera markedly increased IgM production without affecting IgG production (Table VII).

\section{Discussion}

Hyperelevation of serum IgM levels is a major characteristic of TSS. This finding cannot be explained solely on the basis of elevated levels of IgM antibodies to specific malarial antigens: a large proportion of serum IgM reacts with other, mostly unidentified antigens $(1,2)$. This observation has prompted the hypothesis that the polyclonal gammopathy of TSS results from hyperproduction of immunoglobulins (mostly IgM) by B lymphocytes activated by malarial antigens or mitogens. This, in turn, is believed to reflect an imbalance in the number and/or activity of immunoregulatory $T$ lymphocytes in patients with this syndrome $(4,5)$. In a previous study, we found that Indonesian patients with TSS lacked circulatory lymphocytes of the $\mathrm{T}^{+}$(suppressor/cytotoxic) phenotype (5). The studies reported herein indicate that these individuals are deficient in a subset of lymphocytes contained within the $\mathrm{T}^{+}$population,

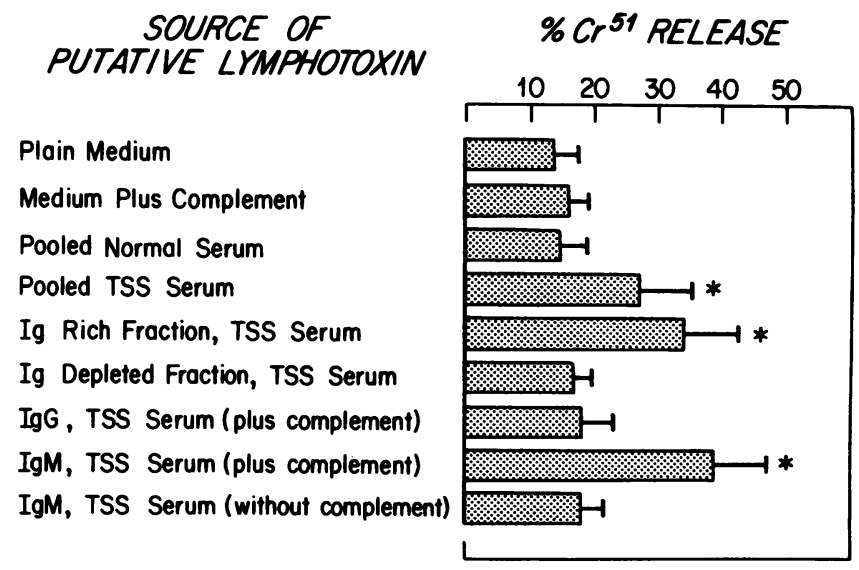

Figure 2. The lymphocytotoxic activity of TSS sera is a complementfixing IgM antibody. Except where indicated, results shown are mean \pm 1 SD of ${ }^{51} \mathrm{Cr}$ released by MNC incubated with sera and serum fractions listed in the presence of complement. * Significant ${ }^{51} \mathrm{Cr}$ release over background ( $P<0.05$ by $t$ test). 
Table VI. Lymphotoxin of TSS Sera Preferentially Kills Mitogen-activated $T 8^{+}$Lymphocytes

\begin{tabular}{|c|c|c|c|c|}
\hline \multirow[b]{3}{*}{ Source of putative lymphotoxin } & \multicolumn{4}{|c|}{ \% ${ }^{51} \mathrm{Cr}$ release* } \\
\hline & \multicolumn{2}{|c|}{ Unstimulated } & \multicolumn{2}{|c|}{$\begin{array}{l}\text { Concanavalin A } \\
\text { stimulated }\end{array}$} \\
\hline & $\mathrm{T4}^{+}$cells & $\mathrm{TB}^{+}$cells & $\mathrm{T4}^{+}$cells & $\mathrm{T}^{+}$cells \\
\hline & $\%$ & $\%$ & $\%$ & $\%$ \\
\hline Medium only & 13 & 13 & 23 & 22 \\
\hline Medium and complement & 13 & 15 & 25 & 25 \\
\hline $\begin{array}{l}\text { Normal serum and } \\
\text { complement }\end{array}$ & \multicolumn{3}{|c|}{ Normal serum and } & 26 \\
\hline \multicolumn{5}{|c|}{ TSS serum and complement } \\
\hline 1 & 16 & 22 & 26 & 42 \\
\hline 2 & 15 & 21 & 33 & 49 \\
\hline 3 & 14 & 31 & 22 & 52 \\
\hline 4 & 16 & 28 & 29 & 48 \\
\hline 5 & 17 & 32 & 28 & 49 \\
\hline
\end{tabular}

* Mean of three experiments performed in triplicate. Values in italic type are statistically significant from the appropriate control values $(P$ $<0.05$ by $t$ test). Concanavalin A-activated $\mathrm{T}^{+}$lymphocytes are more susceptible to the lytic action of TSS sera than nonactivated cells from the same donors.

namely, $T$ cells that function as suppressor cells of immunoglobulin $\mathbf{M}$ production.

It is unlikely that the patients' $B$ cells themselves are abnormal, because their elevated IgM production could by readily suppressed by co-culture with $\mathrm{T}^{+}$lymphocytes from normal donors. This suggests that B cells from patients with TSS may already be activated in vivo. Consistent with this view is our findings that unstimulated (by PWM) B cells from patients with TSS produce more IgG in vitro than cells from distant control donors. The results of co-culture experiments also fail to support the thesis that hyperglobulinemia in TSS is caused by hyperactivity of $\mathrm{T}^{+}$helper cells.

Because of social, cultural, and medical constraints, it was not possible to obtain from all donors the large amounts of blood that are required to perform co-cultures of purified cell populations from the same donor. However, because co-

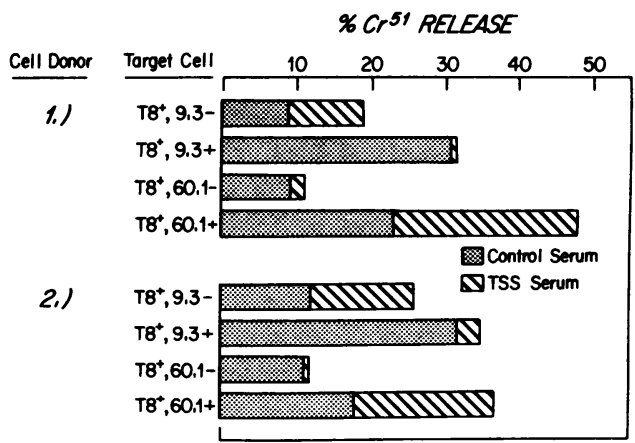

Figure 3. Phenotype of the target cells of TSS lymphotoxins. Results shown were obtained by incubating cells from two normal donors with serum from one patient with TSS. Similar results were obtained with two other TSS sera. Only $\mathrm{T}^{+}, 9.3^{-}$and $\mathrm{T}^{+}, 60.1^{+}$cells are killed by TSS lymphotoxins.
Table VII. Effect of Treatment with TSS Sera on Immunoglobulin Production by MNC from Normal Donors

\begin{tabular}{|c|c|c|c|c|}
\hline \multirow{3}{*}{$\begin{array}{l}\text { Origin of serum } \\
\text { used to treat } \\
\text { MNC suppressor } \\
\text { cells }\end{array}$} & \multicolumn{4}{|c|}{ \% of control production ${ }^{*}$} \\
\hline & \multicolumn{2}{|l|}{ IgM } & \multicolumn{2}{|l|}{$\lg G$} \\
\hline & Exp. 1 & Exp. 2 & Exp. 1 & Exp. 2 \\
\hline & $\%$ & $\%$ & $\%$ & $\%$ \\
\hline \multicolumn{5}{|l|}{ Village control } \\
\hline 1 & 106 & 89 & 108 & 87 \\
\hline 2 & 85 & 92 & 72 & 116 \\
\hline \multicolumn{5}{|l|}{ TSS donor } \\
\hline 1 & 141 & 176 & 89 & 76 \\
\hline 2 & 193 & 207 & 106 & 99 \\
\hline 3 & 246 & 198 & 117 & 86 \\
\hline
\end{tabular}

* Calculated as percent of IgM or IgG produced by the same number of MNC treated with complement only. All cultures consisted of 1 $\times 10^{6}$ viable $\mathrm{MNC}$ stimulated with PWM.

cultivation of syngeneic or of allogeneic cells yielded similar overall results, it is unlikely that allogeneic effects introduced a major bias in the results we report. Studies by others reveal that mixing cells from different donors has little effect on immunoglobulin synthesis in vitro (12).

The loss of suppressor T cell function in TSS is associated with the presence in serum of IgM antibodies that are selectively cytotoxic for a subpopulation of $\mathrm{T}^{+}$lymphocytes, i.e., cells with the $\mathrm{T}^{+}, 60.1^{+}$, phenotype. After activation with concanavalin $\mathrm{A}, \mathrm{T}^{+}$cells become more susceptible to TSS lymphotoxins than their nonactivated counterparts. This suggests that activated suppressor $\mathrm{T}$ cells are the targets of lymphocytotoxic antibodies present in sera from patients with TSS. The differential effect of these cells on IgM vs. IgG production further indicates a deletion of a specific subset of $\mathrm{T}^{+}$suppressor cells.

Although our studies indicate that actual destruction of suppressor cells may contribute to the immunoregulatory abnormalities associated with TSS, we cannot rule out the possibility that the anti-T cell antibodies that we describe could operate in vivo by noncytotoxic mechanisms, e.g., by altering lymphocyte traffic or homing patterns. In this context, it is of interest that sera from patients with systemic lupus erythematosus contain both cytotoxic antibodies to suppressor $T$ cells and antibodies that interfere with suppressor cell activity by a noncytolytic mechanism $(13,14)$. Sequestration of $\mathrm{T}$ cells in spleens has been invoked to explain the temporary decreases in circulating $T$ cells during acute malaria attacks $(15,16)$. Cold-reactive lymphocytotoxins are present in sera from such patients (17). However, the relative percentage of $T$ and B cells in splenic aspirates of patients with TSS is reported to be similar to that in uninfected controls (18). Thus, whether the immunoregulatory dysfunction in TSS is caused by cytolytic or noncytotoxic effects of antisuppressor $T$ cell antibodies remains an unsettled question, but current evidence favors the former possibility.

Polyclonal macroglobulinemia is observed during many parasitic infections, most notably in African trypanosomiasis, chronic malaria, and lepromatous leprosy $(5,19,20)$. It is often assumed that this results from nonspecific stimulation of host immunity by mitogenic products of the infecting 
organisms $(21,22)$. However, both in leprosy (20) and (as reported here) in TSS, abnormal suppressor $\mathrm{T}$ cell activity appears to be the prime cause of hyperproduction of immunoglobulins. This suggests that such mitogens may preferentially activate certain subpopulations of lymphocytes. This appears to be the case in brugian filariasis (Wadee, A. A., and W. F. Piessens, submitted for publication).

Two of the changes found in the present study, IgM lymphocytotoxic antibodies and deficient concanavalin Ainduced suppressor activity, have been described in patients with acute malaria, who typically develop transient splenomegaly $(17,23,24)$. Thus, it is possible that similar immunologic imbalances contribute to the transient splenomegaly in patients with acute malaria and the persistent splenic enlargement in patients with TSS. Why then do only a minority of patients with malaria develop TSS? A major difference between patients with this syndrome and those with classic malaria is the absence of functional immunity in the former $(25,26)$. Thus, one would expect that immunologic disturbances such as the ones we describe would be transient in individuals with acute malaria who develop resistance to the parasite and thereby eliminate the cause of the abnormalities, but would persist in patients with TSS who fail to do so. Reversal of immune aberrations in persons with TSS treated with antimalarials is consistent with this point of view $(1,2,5)$.

Our findings in TSS are similar to those reported in systemic lupus erythematosis by Morimoto et al. (13). In both diseases, autoantibodies to multiple self antigens arise in the context of polyclonal activation of host immunity $(27,28)$. Marked differences exist in the course of parasitic infections in normal mice vs. mice with a genetic predisposition to autoimmunity (29). Because only a minority of residents of malarious areas develop TSS, it is tempting to speculate that this syndrome occurs only in persons who are intrinsically prone to autoimmune diseases. This highly speculative interpretation of the findings we report remains to be tested by long-term prospective studies on residents of areas where TSS is common. Studies designed to identify risk factors that allow the development of this syndrome are in progress.

\section{Acknowledgments}

We are indebted to Dr. Iskak Koiman, head of the Center for Infectious Disease Research, Jakarta, Indonesia, for support and encouragement; to Benedictus Ada, Petrus Patut, Iwa Wiady, Syahrial Harun, Sofyan Masbar, Jan Rush, Margreet Djuanda, and Azalia Sinto for their technical support; to Dr. Hendrikus Fernandez and the Nusa Tenggara Timur Provincial Health Services, Dr. Arwati Supanto and the staff of the Malaria Section of the Center for Disease Control of Indonesia, Bapak Bupati Frans Burhan and the Kabupaten Manggarai Government, Bapak Camat Alo G. A. Mao and the Kecamatan Reok staff, and Bapak Theodorus Morus and the Robek village staff, for their support; to Lieutenant Cynthia DiLorenzo for administrative support; and to Andrea Nurjadi, Astrid Lesiasel, Laili Hadin, and Ramona Gonski for assistance in the preparation of the manuscript. We also thank Dr. J. A. Hanson for his generous gift of 9.1 and 60.3 monoclonal antibodies.

This work was supported in part by grant R01-AI 20102 from the National Institutes of Health, the Rockefeller Foundation, the Filariasis Component of the United Nations Development Programme/World Bank/World Health Organization Special Programme for Research and Training in Tropical diseases, and the Naval Medical Research and Development Command, Navy Department, for work unit 3M 161 102BS10.AF.428.

\section{References}

1. Marsden, P. D., and C. G. Crane. 1976. The tropical splenomegaly syndrome: a current appraisal. Rev. Inst. Med. Trop. Sao Paulo. 18: 54-70.

2. Greenwood, B. M., and Y. M. Fakunle. 1979. The tropical splenomegaly syndrome: a review of its pathogenesis. In The role of the spleen in the immunology of parasitic diseases. Schwabe, Basel. 229-244.

3. Fakunle, Y. M., and B. M. Greenwood. 1976. A suppressor T cell defect in tropical splenomegaly syndrome. Lancet. 2:608-609.

4. Crane, C. G. 1977. The pathogenesis of tropical splenomegaly syndrome: the role of immune complexes. Papua New Guinea Med. J. 20:6-14.

5. Hoffman, S. L., W. F. Piessens, S. Ratiwayanto, P. R. Hussein, L. Kurniawan, P. W. Piessens, J. R. Campbell, and H. A. Marwoto. 1984. Reduction of suppressor T lymphocytes in the tropical splenomegaly syndrome. New Engl. J. Med. 310:337-341.

6. Piessens, W. F., F. Partono, S. L. Hoffman, S. Ratiwayanto, P. W. Piessens, J. R. Palmieri, I. Koiman, D. T. Dennis, and W. P. Carney. 1982. Antigen-specific suppressor $T$ lymphocytes in human lymphatic filariasis. New Engl. J. Med. 307:144-148.

7. McLachlan, S. M., B. R. Smith, and R. Hall. 1978. Kinetics of immunoglobulin production by cultured human peripheral blood lymphocytes. J. Immunol. Methods 21:211-216.

8. Butterworth, A. E., R. F. Sturrock, V. Houba, and P. H. Rees. 1974. Antibody-dependent cell-mediated damage to schistosomula in vitro. Nature (Lond.). 252:503-505.

9. Lum, L. G., N. Orcutt-Thordarson, M. C. Seigneuret, and J. A. Hansen. 1982. In vitro regulation of immunoglobulin synthesis by $\mathrm{T}$-cell subpopulations defined by a new human $\mathrm{T}$ cell antigen (9.3). Cell Immunol. 72:122-129.

10. Chase, M. W., and C. A. Williams. 1968. Chemical analyses. Methods Immunol. Immunochem. 2:251-252.

11. Fakunle, Y. M., and B. M. Greenwood. 1976. Metabolism of IgM in Tropical Splenomegaly Syndrome. Trans. R. Soc. Trop. Med. Hyg. 70:346-348.

12. Waldmann, T. W., and S. Broder. 1982. Polyclonal B cell activators in the study of the regulation of immunoglobulin synthesis in the human system. Adv. Immunol. 32:1-63.

13. Morimoto, C., E. L. Reinherz, T. Abe, M. Homma, and S. F. Schlossman. 1979. Characteristics of anti T cell antibodies in SLE: evidence for selective reactivity with normal suppressor cells defined by monoclonal antibodies. Clin. Immunol. Immunopathol. 16:474484.

14. Sagawa, A., and N. I. Abdou. 1979. Suppressor-cell antibody in systemic lupus erythematosus: possible mechanism for suppressor cell dysfunction. J. Clin. Invest. 63:536-539.

15. Wyler, D. J. 1976. Peripheral lymphocyte subpopulations in human falciparum malaria. Clin. Exp. Immunol. 23:471-476.

16. Wells, R. A., K. Pavanand, S. Zolyomi, B. Permpanick, and R. P. MacDermott. 1979. Loss of circulating T lymphocytes with normal levels of $B$ and null lymphocytes in Thai adults with malaria. Clin. Exp. Immunol. 35:202-209.

17. Wells, R. A., K. Pavanand, S. Zolyomi, B. Permpanick, and R. P. MacDermott. 1980. Anti-lymphocytotoxic antibodies in sera of Thai adults infected with Plasmodium falciparum or Plasmodium vivax. Clin. Exp. Immunol. 39:663-667.

18. Fakunle, Y. M., A. J. Oduloju, and B. M. Greenwood. 1978. $T$ and B lymphocyte subpopulations in the Tropical Splenomegaly Syndrome. Clin. Exp. Immunol. 33:239-243.

19. Goidl, E. A., and P. D. Marsden. 1974. Immunoglobulins in African trypanosomiasis. Lancet. 1:690-692.

20. Bullock, W. E., S. Watson, K. E. Nelson, V. Schauff, S. Makonkawkeyoon, and R. R. Jacobson. 1982. Aberrant immunoregulatory control of B lymphocyte function in lepromatous leprosy. Clin. Exp. Immunol. 49:105-114. 
21. Greenwood, B. M. 1974. Possible role of a B cell mitogen in hypergammaglobulinemia in malaria and trypanosomiasis. Lancet. 1 435-436.

22. Wyler, D. J., and J. J. Oppenheim. 1974. Lymphocyte transformation in human falciparum malaria. J. Immunol. 113:449-454.

23. Gilbreath, M. J., K. Pavanand, R. P. MacDermott, R. S. Wells, and M. S. Ussery. 1983. Characterization of cold reactive lymphocytotoxic antibodies in malaria. Clin. Exp. Immunol. 51:232-238.

24. Gilbreath, M. J., R. P. MacDermott, K. Pavanand, P. Phisphumvithi, S. Kongchareon, and T. Winnonwattawattee. 1983. Deficiency of Con A-induced suppressor cell activity in peripheral blood mononuclear cells from Thai adults naturally infected with Plasmodium faliciparum and Plasmodium vivax. Parasite Immunol. (Oxf.). 5:431440.

25. Jensen, J. B., S. L. Hoffman, M. T. Boland, M. A. S. Ahood,
L. W. Laughlin, L. Kurniawan, and H. A. Marwoto. 1984. Comparison of immunity to malaria in Sudan and Indonesia: crisis-form versus merozoite invasion inhibition. Proc. Natl. Acad. Sci. USA. 81:922925.

26. Cox, F. E. G. 1984. Malarial immunity: Indonesian and Sudanese style. Nature (Lond.). 309:402-403.

27. Koffler, D., P. H. Schur, and H. G. Kunkel. 1967. Immunological studies concerning the nephritis of systemic lupus erythematosus. $J$. Exp. Med. 126:607-623.

28. Wells, J. V. 1970. Immunological studies in Tropical Splenomegaly Syndrome. Trans. R. Soc. Trop. Med. Hyg. 64:531-546.

29. Boyer, M. H., R. Hoff, T. L. Kipnis, E. D. Murphy, and J. B. Roths. 1983. Trypanosoma cruzi: susceptibility in mice carrying mutant gene lpr (lymphoproliferation). Parasite Immunol. (Oxf.). 5:135-142. 